\title{
THE PROGRESS OF TRY (TURKISH LIRA) DEPOSITS IN BANKS WITH DIFFERENT MATURITIES AFTER WITHHOLDING TAX RATE CHANGE FOR DEPOSITS
}

\author{
DOI: 10.17261/Pressacademia.2021.1525 \\ PAP- V.14-2021(51)-p.171-172
}

\section{Huseyin Ocal}

Istanbul Gelisim University, Business Administration, Istanbul, Turkey. hocal@gelisim.edu.tr, ORCID: 0000-0002-2614-8199

\section{To cite this document}

Ocal, H., (2021). The progress of TRY deposits in banks with different maturities after withholding tax rate change for deposits. PressAcademia Procedia (PAP), 14, 171-172.

Permanent link to this document: http://doi.org/10.17261/Pressacademia.2021.1525

Copyright: Published by PressAcademia and limited licensed re-use rights only.

\section{ABSTRACT}

Purpose- TRY deposit withholding tax rate has been reduced from 15\% to 5\% for demand and time deposit accounts with up to 6 months (including six months) maturity, $12 \%$ to $3 \%$ for time deposits with maturity up to 1 year (including one year) and $10 \%$ to $0 \%$ for deposit accounts with a maturity longer than one year with the Presidential Decree dated September 29, 2020, and numbered 3032. The study aims to reveal how this decision, which was taken to encourage TRY deposits and spread them over the long term, affects the progress of TRY deposits in banks with different maturities.

Methodology- TRY deposit has been examined with different maturities (demand, 1-month maturity, 3-month maturity, 6-month maturity, 1-year and longer maturity) fourteen months before the effective date of the decree and ten months afterward. Therefore, the TRY deposit amount with different maturities is divided by the total TRY deposit amount to find the deposit percentages with different maturities monthly.

Findings- Total TRY demand deposits to total TRY deposits ratio was $22.97 \%$ in September 2020. After being at the lowest level (20.63\%) in January 2021, following October 2020(when the withholding tax was reduced), it started to rise again slightly and increased to $23,57 \%$ in July 2021. One-month TRY deposits to total TRY deposits ratio was $23.19 \%$ in September 2020; it slightly increased (25.07\%) for two months following October 2020 and then decreased to the lowest level (18.38\%) in May 2021. The three-month TRY deposits to total TRY deposits ratio was 48.26\% in September 2020; it increased (52.17\%) in the four months following October 2020 and decreased slightly to $49.53 \%$ in July 2021. Six-month TRY deposits to total TRY deposits ratio was 3.08\% in September 2020; it decreased slightly (2.68\%) in the two months following October 2020 and increased slightly for six months to 4.91\% in May 2021. It decreased slightly again in June and July 2021. TRY deposits with a maturity of one year and longer to total TRY deposits ratio was $2.50 \%$ in September 2020 . It increased slightly to $4.72 \%$ in the eight months following October 2020. It decreased slightly in June and July 2021.

Conclusion- After the withholding tax rate change, TRY demand deposit to total TRY deposit and 1-month maturity TRY deposit to TRY deposit ratios decreased. The result is expected. Because shifting short-term deposits to longer-term deposits is one of the objective of changing the withholding tax rates. Thus, the change in the withholding tax rates has served for its purpose. When 3-month TRY deposits to total TRY deposits ratio is analyzed, an increase is observed after the withholding tax change. The decrease in the ratio of TRY demand deposits to total TRY deposits and 1-month maturity TRY deposits to total TRY deposits paved the way for an increase in the ratio of 3-month TRY deposits to total TRY deposits. The same explanation also holds the ratio of TRY deposits with a maturity of 6 months to the total TRY deposits and the ratio of TRY deposits with a maturity of 1 year or longer to the total TRY deposits. However, the most significant impact of the withholding tax change is observed in the shift from 1-month deposits to 3-month deposits.

Keywords: Bank deposit maturities, TRY deposit withholding tax rate change (September 29, 2020), TRY deposit incentive JEL Codes: G21 


\section{MEVDUAT STOPAJ ORANLARI DEĞişTiRILDIKTEN SONRA VADELERINE GÖRE TRY(TÜRK LIRASI) MEVDUATIN GELIŞiMi}

\section{ÖZET}

Amaç- 29 Eylül 2020 tarih ve 3032 Sayılı Cumhurbaşkanlığı Kararnamesi ile TRY mevduat stopaj oranları vadesiz ve ihbarlı hesaplar ile 6 aya kadar(6 ay dahil) vadeli hesaplarda \%15'ten \%5'e, 1 yıla kadar (1 yıl dahil) vadeli hesaplarda 12'den \%3'e ve 1 yıldan uzun vadeli hesaplarda $\% 10$ 'dan \%0'a düşürülmüştür. Çalışmanın amacı, TRY mevduatı teşvik ve uzun vadeye yaymak için alınan bu kararın vadelerine göre bankalardaki TRY mevduat gelişimini nasıl bir etkilediğini ortaya koymaktır.

Yöntem- Kararnamenin yürürlüğe girdiği tarihten önceki ondört ay ve sonraki on ay TRY mevduatlar vadelerine(vadesiz, 1 ay vadeli, 3 ay vadeli, 6 ay vadeli, 1 yıl ve daha uzun vadeli) göre incelenmiştir. Yukarıda belirtilen vadelerdeki TRY mevduat tutarı toplam TRY mevduat tutarına bölünerek aylar bazında vadelerine göre mevduat yüzdeleri belirlenmiştir.

Bulgular- Toplam TRY vadesiz mevduatın toplam TRY mevduata oranı Eylül 2020 ayında \%22,97 iken stopajın düşürüldüğü Ekim 2020' yi takiben Ocak 2021'de en düşük seviyesini(\%20,63) gördükten sonra tekrar hafif yükselişe geçmiş olup, Temmuz 2021'de \%23,57 seviyesine çıkmıştır. Bir ay vadeli TRY mevduatın toplam TRY mevduata oranı Eylül 2020 ayında \%23,19 iken stopajın düşürüldüğü Ekim 2020' yi izleyen iki ay hafif yükselmiş(\%25,07) sonrasında düşüşe geçerek Mayıs 2021 'de en düşük seviyesi olan \%18,38'e gerilemiştir. Üç ay vadeli TRY mevduatın toplam TRY mevduata oranı Eylül 2020 ayında \%48,26 iken stopajın düşürüldüğü Ekim 2020' i izleyen dört ay yükselmiş(\%52,17) sonrasında hafif düşüşe geçerek Temmuz 2021'de \%49,53 seviyesine gerilemiştir. Altı ay vadeli TRY mevduatın toplam TRY mevduata oranı Eylül 2020 ayında \%3,08 iken stopajın düşürüldüğü Ekim 2020' yi izleyen 2 ay hafifçe düşmüş $(\% 2,68)$ sonrasında altı ay hafif yükselerek Mayıs 2021'de \%4,91 seviyesine çıkmıştır. Haziran ve Temmuz 2021'de tekrar hafifçe düşmüştür. Bir yıl ve daha uzun vadeli TRY mevduatın toplam TRY mevduata oranı Eylül 2020 ayında \% 2,50 iken stopajın düşürüldüğü Ekim 2020' yi izleyen sekiz ay hafifçe yükselerek \%4,72 seviyesine çıkmıştır. Haziran ve Temmuz 2021'de hafifçe düşmüştür.

Sonuç- Stopaj değişikliği sonrası vadesiz TRY mevduatın toplam TRY mevduata ve 1 ay vadeli TRY mevduatın toplam TRY mevduata oranlarında düşme görülmektedir. Bu beklenen bir sonuçtur. Çünkü stopaj oranlarındaki değişikliğin sebeplerinden bir tanesi TRY mevduatı uzun vadeye yaymaktır. Bu çerçevede, stopaj oranlarındaki değişiklik amacına ulaşmıştır. 3 ay vadeli TRY mevduatın toplam TRY mevduata oranı incelendiğinde stopaj değişikliği sonrası artış görülmektedir. Vadesiz TRY mevduatın toplam TRY mevduata ve 1 ay vadeli TRY mevduatın toplam TRY mevduata oranlarında düşmenin neticesinde 3 ay vadeli TRY mevduatın toplam TRY mevduata oranında artış mümkün olmuştur. Bu durum 6 ay vadeli TRY mevduatın toplam TRY mevduata oranı ve 1 yıl ve daha uzun vadeli TRY mevduatın toplam TRY mevduata oranı için de geçerlidir. Ancak stopaj değişikliğinin en büyük etkisi 1 ay vadeli mevduattan 3 ay vadeli mevduata geçişte görülmektedir.

Anahtar Kelimeler: Banka mevduat vadeleri, TRY mevduat stopaj değişikliği (29 Eylül 2020), TRY mevduat teşvik JEL Kodları: G21

\section{REFERENCES}

Akan, N. B. (2008). Likidite Riski Ölçümü. Bankacılar Dergisi, 66, 180-191.

Arabacı, H., \& Yucel, D. (2020). Pandeminin Türkiye ekonomisine etkileri ve Türkiye merkez bankası tarafından finansal istikrarı sağlamak amacıyla alınan önlemler. Sosyal Bilimler Araştırma Dergisi, 9(2), 91-98.

Ergeç, E. H., \& Asutay, M. (2018). Kar payı ve mevduat faizi ilişkisinde neden ve sonuçlar. İktisat Dergisi, 1(1), 70-86.

GÜL, A. B. (2017). Türk bankacılık sisteminde konut kredileri: ipotek teminatlı menkul kıymet ve ipoteğe dayalı menkul kıymet uygulamaları. Finansal Araştırmalar ve Çalışmalar Dergisi, 9(16), 39-58.

Güngör, B., \& Dilmaç, M. (2020). Finansal kriz ortamlarında sermaye yapısının bankaların finansal performanslarına etkileri. Muhasebe ve Finansman Dergisi, (85), 153-172.

Selimler, H. (2015). Sorunlu kredilerin analizi, banka finansal tablo ve oranlarına etkisinin değerlendirilmesi. Finansal Araştırmalar ve Çalışmalar Dergisi, 7(12), 131-172.

www.resmigazete.gov.tr (2020). 29 Eylül 2020 tarihli ve 3032 sayılı Cumhurbaşkanı kararının eki karar. https://www.resmigazete.gov.tr/eskiler/2020/09/20200930-18.pdf (10 Eylül 2021'de ulaşıldı).

www.tcmb.gov.tr (2021). Vade gruplarına göre mevduat.

https://evds2.tcmb.gov.tr/index.php?/evds/serieMarket/collapse_4/5899/DataGroup/turkish/bie_kmmbgmv/( 12 Eylül 2021'de ulaşıldı).

Zengin, S., \& Yüksel, S. (2016). Likidite riskini etkileyen faktörler: Türk bankacılık sektörü üzerine bir inceleme. 